\title{
Civilians, Arms and Endemic Conflicts in Africa
}

\author{
Michael I. Ogu \\ Department of Political Science and Public Administration, Babcock University, Ogun State, Nigeria \\ Email:ogumyk@gmail.com
}

\begin{abstract}
How did arms ever get into the hands of civilians in the first place? We are aware of the fact that arms, to a large extent, were originally designed to serve as deterrence against forms of external aggression on territorial sovereignty. In the African case, arms are arguable believed to have gained access into the continent via colonialist activities, and could never have been intended for civilian uses. The current trend of conflict event in Africa shows that civilians are dominant participants in the several conflict situations in Africa. This study will attempt to discover what has lead to this unfortunate situation.

This researcher consulted several scholarly secondary sources of information in generating data for this study, making the work more of a qualitative research.

Several social, economic and maybe physical factors are responsible for the incessant use of arms by civilians: failure of governance, declining economic capacity of states, growing youthful population, the list goes on. If one is to make any predictions, following the trend of events, civilians, unfortunately, will remain key actors in the use of arms for the foreseeable future, in fact this may well be just the beginning of non-state actors getting involved with arms.
\end{abstract}

Key Words: Arms, Conflicts, Non-state Actors, Civilians, Light Weapons

\section{Introduction}

The United Nations Development Programme has reported that there are about eight million illegal weapons in West Africa, and Nigeria accounts for 70 percent of this statistics (Tell Magazine; August 26, 2013). Worse still, Shehu Abdul-Kadir, a Major General in the Nigerian Army and Commander of the International Support Mission to Mali was reported to have declared before an audience that West Africa contains about 10 million illegal weapons and Nigeria makes up 70 percent of this statistics as well. These disturbing statistics have remained a principal agenda item for policy makers at national, regional and international levels.

Africa is believed to be a colonial creation; it can be argued that 'it took the coming of the colonialist for us to know that we are Africans'. Prior to the adventures of the Portuguese; Prince Henry and Vasco de Gama, on the African coast, and the subsequent demarcation of Africa among the seven European powers; Belgium, Britain, France, Germany, Italy, Portugal and Spain, resulting from the 1884/85 Berlin conference, individuals communities were organized as clans, villages or Kingdoms and administered under several systems of government which they found useful and able to solve their problems. Although "both segmented and centralized political systems maintained impressive arrays of foreign relations within their respective regions", (Schraeder, 2004), conflicts when they arose, involved mainly crude weapons which were perhaps not capable of 'third party' damage.

Africa, like most other nations of the world, if not all, has a military foundation. Most of the modernday African states, with the exception of Liberia and Ethiopia, were creatures of imperialism; which more or less means force. In maintaining peace and order in the conquered territories, the colonialist established, from among the African people, military institutions (which did not have a capacity comparable to many other military institutions) and armed them with more sophisticated weapons, which, arguably, can be regarded as the earliest introduction of arms into the continent.

Philip and Wilson (2012) did a study on the estimation of small arms in the possession of civilians across the African continent, as compared to those of other countries and continents of the world. The report of this shows that the estimated civilian gun possession rates in Central Africa, range from 1.1 and 1.4 firearms per 100 people in Chad and the Democratic Republic of Congo (DRC) respectively, to highs of 14.0, 17.3 and 19.9 per 100 people in Gabon, Angola and Equatorial Guinea - three of Africa's four most heavily armed civilian populations. In 2004, with an estimated 2.8 million privately held firearms, Angola was ranked the world's 28th most-armed civilian population - at that time the highest rate of private gun ownership in Central Africa, and second only to South Africa as the continent's most heavily armed nation. In North Africa, the estimated civilian gun possession rates ranged from Africa's lowest, Tunisia ( 0.1 firearms per 100 people), to one of Africa's highest, Libya (15.5). The remainder ranged from 3.5 in Egypt to 7.6 in Algeria - excluding Western Sahara. In 
East Africa, the estimate ranged from 0.4, 0.5, and 0.6 guns per 100 people in Ethiopia, Eritrea and Rwanda respectively, to 5.4 in Seychelles, 9.1 in Somalia and 14.7 in Mauritius.

The entire globe is challenged by the proliferation of small arms, or firearms or guns, as they are also commonly called. Such weapons, according to reports by the International Action Network on Small Arms (2006) and the Geneva Declaration in 2008, are used to kill as many as 1,000 people each day. There are more than 875 million firearms in the world, 75 per cent of them in the hands of civilians (Karp, 2007). Guns outnumber passenger vehicles by 253 million, or 29 per cent (Renner, 2008). Further, according to Batchelor (2001); Batchelor (2003) and Fahrenthold and Kunkle (2009), "each year about eight million new small arms, plus 10 to 15 billion rounds of ammunition are manufactured - enough bullets to shoot every person in the world not once, but twice". Little wonder, the former United Nations Secretary-General - Kofi Annan - stated, in his report to the Millennium Assembly of the United Nations that, "the death toll from small arms dwarfs that of all other weapons systems - and in most years greatly exceeds the toll of the atomic bombs that devastated Hiroshima and Nagasaki. In terms of the carnage they cause, small arms, indeed, could well be described as 'weapons of mass destruction'."

\section{Conceptual Elucidation}

In ensuring the relevance of this study to a wider population of readers and subject it to more logical and meaningful critique by scholars in the field under study, it is imperative to clearly define some of the key terms that are contained in this study. This would allow for critique and discussion of this study within the context of its authorship.

Civilians: A civilian, according to Article 50 of the United Nations 1977 Protocol additional to the Geneva Conventions of 12 August 1949, and relating to the protection of victims of international armed conflicts (Protocol I), is "any person who does not belong to armed forces of a particular state or country". Hence, any individual or group that have not been legally or officially recruited into the country's armed forces - Army, Navy or Air Force - or other managers of force, is(are) regarded as a civilian(s).

Arms: There is really not a specific, unanimous or widely acceptable definition of small arms and light weapons. The Small Arms Survey, accepting the proposal of the 1997 United Nations Panel of Governmental Expert, considers portability a defining characteristic of small arms. Small arms therefore refer to "weapons that fire a projectile and may be carried by an individual, a small number of people, or transported by a pack animal or a light vehicle". Such weapons include: revolvers and self-loading pistols, rifles and carbines, assault rifles, sub-machine guns and light machine guns, heavy machine guns, hand-held under-barrel and mounted grenade launchers, portable anti-aircraft guns, portable anti-tank guns, recoilless rifles, portable launchers of anti-tank missile and rocket systems; portable launchers of anti-aircraft missile systems (MANPADS); and mortars of calibres of less than 100mm (Small Arms Survey).

Endemic Conflicts: This study defines conflict as confrontation(s) between individuals or among groups over scarce resources or disagreements, clashes or discordance in interests, ideas or opinions. Conflicts are endemic when they are prevalent, rampant, widespread or common in a certain area or location. Hence, with the frequency of conflict occurrences across the continent, conflict in Africa is arguably endemic.

\section{Endemic Conflicts In Africa}

By the 1950s when independent rule returned to Africa, there were very high hopes among individuals and institutions, both within and outside the continent that Africa could become the pride of other continents if the right institutions would be built and the apparatus of leadership would be entrusted in the right quarters. However, starting with the conflict in Congo in the early 1960s, although was thought to be an anomaly or an unexpected turn and also attracted United Nations Peace-Keeping efforts as well as other genuine international responses (Osaghae, 1994), there have been several other conflicts situations across the continent. In fact, less than two decades from 1960, Osaghae (1994) asserts that several 'nation-threatening' conflicts have occurred and certain clear patterns had emerged which prompted the conclusion among academics and others individuals and groups or organizations, that Africa was 'conflict-endemic'.

Between 1960 and the 1980s, African has witnessed several conflicts, notable among which are the arguably irreconcilable conflict in Rwanda and Burundi between the Hutu and Tutsi ethnicities, the crisis in Sudan, the conflicts in Uganda and Ethiopia, attempted secession of the Republic of Biafra from Nigeria in the late 1960s and the resultant civil war with the Federal Republic of Nigeria, the violent conflicts in South Africa over the apartheid regime, and even more recently, the conflicts in Mali and the revolutions in North Africa's Tunisia, Egypt and Libya, the seemingly nonnegotiable demands of the Boko Haram sect in Nigeria and the increased killings and bombings of innocent citizens, especially in Northern Nigerian, the list goes on.

Although there are no simple or easy explanations for conflicts in Africa, Mazrui (2004) has put forward some explanations, some of which are discussed below: 


\section{Black Violence, White Roots}

Mazrui, affirming the position of Dunnigan and Bay (1996), posits that although the anti-colonial wars were bloody wars fought primarily between blacks and whites, the post-colonial wars have been fought mainly between blacks and they have been more ruthless than were the anti-colonial wars. However, he observes that the 'seeds' of post-colonial wars lie in the sociological and political mess created by 'white' colonialism in Africa: old conflict resolution mechanisms and traditional political institutions were destroyed and there were no effective alternatives. The states created by Europeans had very fragile bases, and worse still, the Africans who took over the governing of these states were not experiences. Hence, several post-colonial conflicts in Africa have been causes by failing states and the lack of capacity by African leaders to properly articulate and deliver on governance.

\section{Are Borders to Blame?}

Prior to the Berlin Conference of 1884/85, and the official demarcation of African territories as well as imposition of boundaries, Africans were living without borders. According to Mazrui (2004), "most people lived in loose groupings. Their territories were unmarked. Empires came and went, absorbing new groups and being assimilated themselves, but possessing few, if any, rigid frontiers". The creation of boundaries by the Europeans confused the already existing systems and institutions in the territory; several nations with diverse traditions, authority and systems of settling disputes were forced to cohabit without the time to become agreeable. In Nigerian state, for instance, three large nations with several other smaller ethnicities within them were forced into what became Nigeria; the Yorubas in the South were different from the Muslim Hausa nation in the North which was also entirely and uniquely different from the 'loose' Igbo nation in the East. This artificial creation lead to the Nigerian civil war (1967 - 1970), which similar to the Ethiopian crisis in the 1980's, was a gruesome war with consequences on children and women and the state itself. The Somali, on the other hand, was a nation divided among four different countries: Djibouti, Ethiopia, Kenya and Somalia, and the desire of this erstwhile united nation to reunite have created severe conflict situations as well on the continent.

\section{Religion or Ethnicity}

Ethnicity and religion has also been a major conflict cause in Africa: Mortimer (1996) asserted that Algeria, arguably, has been described as been afflicted by the worst conflict in North Africa, having been classified to be containing the ugliest and most intractable armed conflicts in the world. Ansari (1984) also asserted that the conflict in Egypt is more or less of a religious base. From the 1990s, the genocide between the Hutu and Tutsi ethnic groups in Rwanda and Burundi (Nyakanvzi, 1998) and the conflict in Somalia (Hashim, 1997), all go to prove this point.

\section{Resources or Identity}

Both resources and identity have also been a major cause of the conflicts in Africa; Mazrui (2004) asserts that while the White and black people fight over 'who owns what', the blacks fight blacks over 'who is who'. In many cases where there have been conflicts between whites and blacks; the South Africa apartheid for instance, such conflicts have majorly been economic, while many cases of blacks fighting blacks have not been economic (in many of such cases, there are no resources to fight for), but about power or cultural differences, an instance is the 1994 Hutu and Tutsi struggle.

\section{Modern Weapons and Pre-modern Armies}

Africa, in the pre-colonial era had near disciplined and professional armies (they were modern to some extent), although these armies had weapons that were not so advanced. Increasingly on the continent, the armies have become less professional and disciplined while the weapons are now more advanced. It must be noted that both the armies and weapons were also legacies of colonialism, which Tanzania, among a few other African countries had an opportunity to disband; Julius Nyerere disbanded the colonial army in 1964, but built a national army as a replacement. Advanced modern weapons and less modern armies are 'dysfunctional twins' which African inherited at independence and these combination has lead to a lot of conflicts as well as induced other conflict situations across the continent.

Although these issues discussed above are not exhaustive on the causes of conflicts in Africa, especially in contemporary times, but they do a lot in explaining the nature of conflicts in Africa in the immediate post-colonial era and in fact provide a background for understanding the nature of the conflicts that are prevalent in Africa even in recent times.

Conflicts in contemporary Africa have evolved over the centuries. The conflicts that plague the continent today are majorly severe armed conflicts with far-reaching consequences on human lives as well as 
social and economic consequences as well. This does not suggest that the conflicts especially in the colonial and early post-colonial era did not involve arms, rather, as a result of the increased arms race and proliferation of small arms and light weapons across the continent, the number of arms on the continent is on the increase and thus the possibility of these weapons inducing conflict is high and the consequences of their use is also devastating. Describing the current nature of conflicts in Africa, Shah (2010), asserted, "if this scale of destruction and fighting was in Europe, then people would be calling it World War III with the entire world rushing to report, provide aid, mediate and otherwise try to diffuse the situation".

Conflicts in Africa today, according to Cilliers and Schünemann (2013), appears to be increasingly fragmented and worse still, the number of actors, particularly non-state actors, involved in conflicts in Africa is on the increase. The conflict in Darfur, Sudan, is a case in point, where the peace process finalized at the All Darfur Stakeholders' Conference in May 2011 (in Doha, Qatar) was significantly altered by the division among various rebel groups. Even more recently, the Séléka coalition in the Central African Republic eventually consisted of five separate groupings; three of these signed a peace agreement with President François Bozize on 13 January 2013. Unfortunately, Bozizé was eventually ousted when the coalition resumed their advance a few months later. Also, the armed conflict in northern Mali, Tuareg and Islamist rebels (previously allies), fought each other in the latter stages of Operation Serval in January 2013 when French forces recaptured Mali's north. In the eastern provinces of the Democratic Republic of Congo, the M23 rebel movement has recently split into different groups on getting the information on the decision to deploy a neutral intervention force as part of the United Nations Organization Stabilization Mission in the region. (Cilliers and Schünemann, 2013)

Several insurgent groups in contemporary Africa have strong transnational connections, capacity and luxury to move, as easily as possible, across borders. A well-known example of these insurgent groups is alQaeda in the Islamic Maghreb, which originally fought to overthrow the Algerian government while consolidating its activities across the Sahel region, particularly in northern Mali. Studies have shown that there is a tendency towards a connection between networks of organized crime as well as their illicit activities, including money laundering, kidnapping, drug trafficking, terrorism, etc. (Shaw and Reitano, 2013)

Straus (2012) also asserted that in line with the rise in political contestations, election related violence has also increased, before, during and after election polls. This is particularly the case in countries where democracy has not been consolidated. Examples include the 2005 elections in Zimbabwe, or where the government has been actively factional in benefitting one ethnic group above others, for instance the December 2007 Kenya elections, which culminated in post-election violence. In Zimbabwe's 2008 presidential elections, more than 200 people died, at least 10000 were injured and tens of thousands were internally displaced due to election-related violence. Other elections that were accompanied by varying levels of violence include those in Nigeria (2011) and Côte d'Ivoire (2011).

Violence over access to resources, such as land and water, is also on the increase and this includes farmer-herder conflicts, such competition at community level has a potential for violence. In 2010 and 2011, conflicts over resources accounted for approximately 35 per cent of all conflicts in sub-Saharan Africa and 50 per cent of conflicts in the Americas. On the other hand, only 10 per cent of all conflicts in Europe, the Middle East and Maghreb, and Asia and Oceania featured resources as a conflict item (Heidelberg Conflict Barometer 2011). In cases of resource conflict, the possession of natural resources and/or raw materials, and the profits derived from them were determining factors in the conflicts. Globally, in this period, almost half of the resource conflicts were violent.

There is also an ongoing debate that the competition over scarce natural resources, particularly food, water, energy and natural resources, to become a major source of future interstate, regional and even international conflict. Lee et.al (2012) has observed that researchers in Defence Industries, in addition to respected think tanks such as the Royal Institute for International Affairs, have been particularly vocal about the 'resource wars of the future'. As world populations continue to grow, competition for food, water and energy inevitably is on the increase. The most recent global trends report published by the National Intelligence Council of the United States in 2012: Global Trends 2030: Alternative Worlds argues that in the next 20 years scarcity could be national or regional in nature, but not global, although the trade-offs between food, water and energy may impact upon one other. The report argues that fragile states in Africa and the Middle East are most at risk for food and water shortages, but China and India are also vulnerable. The report goes on to state that, by 2030, the world will require 35 per cent more food, 40 per cent more water and 50 per cent more energy to cater for a global population of around 8,3 billion people (approximately 1,2 billion more than the present population).

Summarily, the current violent conflicts between states in Africa tend to be on a smaller scale than in previous decades. These conflicts, according to Melander et. al. (2006); Bethany and Gleditsch (2005) and Straus (2012) seems more difficult to resolve as a result of the mobile, factionalized nature of the various armed groups involved in the conflicts; the strong cross-border dimensions; and the ability of insurgents to generate funds from transnational illicit trade, exploitation of local resources, banditry, and/or international terrorist networks rather than principally from external states, examples of such conflicts are prominent in Uganda, 
Chad, the Central African Republic, Ethiopia, Sudan, Mali, Niger, Senegal, Angola, Nigeria and the Democratic Republic of Congo.

\section{Theoretical Base}

The rational choice approach seems the most appropriate approach to this study. The emphasis on the individual interest is always the starting point of the theory (Ogu, 2013). In this approach, individuals ultimately take actions and social actions ... individual actions and social actions are "optimally chosen" and are entirely concerned with the individuals own welfare. These basic assumptions portray the individual as actor with an initial concern only about him or herself, as well as his or her welfare. Individuals, arguing further, are selfmaximizing and self-interested beings who will seek to satisfy their own interests before they can engage in public good (if at all they can).

Stating the essence of this approach, Elster (1989) asserted that "when faced with several courses of action, people usually do what they believe is likely to have the best overall outcome". Beyond the field of economics, which happens to be the founding discipline of the approach, scholars such as Green (2002), Becker (1976), Radnitzky and Bernholz (1987), Hogarth and Reder (1987), Swedberg (1990), and Green and Shapiro (1996), have spread this approach beyond the field of conventional economics to other disciplines, including political science.

The possession and use of small arms and light weapons by civilians in much of Africa have been subjected to several reasons, which are being discussed substantially in this paper. These explanations, it can be argued, are rational and objectives explanations as far as the conflicting parties are concerned, although these explanations may not be rational to other individuals or groups as is the case in many of the examples cited in this study. The rational choice approach holds that individuals, in as much as they are provided with necessary information needed to take a decision, may often muddle through decision making and in this case this has led to conflict that have had far-reaching consequences for the state in Africa.

\section{Civilians In Armed Conflicts}

There have been a lot of policies; national, regional and international, protecting civilians in situations of conflict. The United Nations, at inception in 1945, was preoccupied only with ending wars between states and it abhorred any form of external interference in the affairs of individual states, the United Nations Charter in Article 2(7) clearly stated; "Nothing should authorize intervention in matters essentially within the domestic jurisdiction of any State". However, at the dawn of the 1990s and with the atmosphere of a new system of security internationally, there was some ray of hope in the nature of international response to interstate and intrastate aggression, with the introduction of 'humanitarian intervention' in violent conflicts within states, although this introduction led to a lot of argument within the international community.

In order to provide answers to questions like; "how should the international community respond to catastrophic human rights violations within states, where the state in question claims immunity from intervention based on longstanding principles of national sovereignty? When, if ever, is it right for states to take coercive action, in particular military action, against another state for the purpose of protecting people at risk within it?" (Evans, 2006), there have been debates on moving away from the principles of "humanitarian intervention", toward embracing of a more effective new concept of "the responsibility to protect", especially considering the gross violation of fundamental rights of human across the continents of the world.

The International Commission on Intervention and State Sovereignty (ICISS) set up and sponsored by the Canadian Government in December 2001, and charged with the responsibility of drafting a framework to meet the contemporary security challenge of violations of human rights, submitted a report titled 'responsibility to protect' (this marked the first use of the phrase 'Responsibility to Protect'), which, according to Evans (2006), made four major contributions to the international policy debate, one of which, and perhaps the most important, was to invent a new way of talking about humanitarian intervention; the commission tried to turn the debate from an issue of 'right' to one of 'responsibility' to protect people at grave risk, hence the intervention benefits not the interveners but those needing support. The report observed that in addition to control, a sovereignty state was also obliged with the primary "responsibility" of protecting the people within its borders and when the state fails in this responsibility (either as a result of lack of ability or willingness) the onus rests on the larger international community.

The United Nations Secretary General, in 2004, also set up a panel: the High-level Panel on Threats, Challenges and Change, which further emphasized the principle of the responsibility to protect or "R2P" as it is often called, which was recommended by the ICISS. The report of the panel concluded that the international community, through the Security Council, had a collective responsibility of authorizing military intervention in situations of genocide, ethnic cleansing and any other large-scale killings as well as all serious violations of humanitarian law, however such military intervention measure must be carried out only as a last resort and when sovereign states have failed either powerlessly or unwillingly to prevent such tragedies. The panel further proposed a few basic criteria upon which military intervention should be implemented; seriousness of the 
conflict, proportionality of the response to the conflict and it must be a last resort. At the United Nations World Summit in 2005, all member-states of the United Nations formally subscribed to the R2P and accepted to be guided by its principles. The international community has seen then, made reference to the policy in several conflicts situations, especially across Africa: Libya 2011, Cote d'Ivoire 2011, South Sudan 2011, Yemen 2011, Syria 2012, among others.

According to a 2011 Oxfam report, the statistics of civilian victims in conflicts are:

1. In Somalia, the International Committee of the Red Cross (ICRC) reported more than 6,000 people wounded based on records from Mogadishu's two main hospitals; of these, 40 per cent were women and children. According to UNHCR, at least 7,600 people reported weapons-related injuries, while other reports indicate that at least 2,100 civilian deaths were recorded in Mogadishu alone.

2. Renewed intense fighting in Darfur caused the deaths of at least 2,300 people.

3. In the immediate aftermath of the post-electoral tensions in Côte d'Ivoire, more than 200 people had already been killed by the end of December 2010 .

It is largely true that there is a lot of laudable emphasis in the literature on protection of civilian in cases of armed conflicts, from national, regional and international quarters. This growing awareness has, arguably, reduced to a large extent the number of civilians that otherwise should have been victims of these violent conflict situations. However, it is also worthy of mention that civilians, especially in an age of increasing proliferation of small arms and light weapons, coupled with the growing poverty level and other human security challenges on the continent, possess increased capacity to cause serious damage to state institutions as well as to fellow individuals and even groups. Terrorism, insurgency and counter-insurgency are common themes on the world scene and Africa has had its fair share of this terror, in fact, some literature assert that the terror on state and state institutions caused by civilians is only beginning.

\section{Explanations For Conflict And Arms Proliferation Trends In Africa}

As indicated earlier in this paper, there are several explanations for conflicts in Africa, however, Cilliers and Schünemann (2013) have postulated seven long-standing relationships as basis for explaining the current nature of conflicts in Africa, and can also explain to a very large extent the reasons for increasing proliferation of small arms in Africa: poverty and instability, transitions from autocracy to democracy or adverse regime changes, a large democratic deficit (lack of democracy), a relatively large youthful population that is affected by widespread exclusion, the tendency towards repeat violence (return war), the 'bad-neighborhood' effect of being close to or bordering on other countries experiencing conflict and poor governance, self-serving leadership and the impact of excessive dependence on commodity exports. Some of these positions are further discussed subsequently in this study.

First, and most importantly, is the relationship between poverty and instability. Fearon and Laitin (2003); Collier and Hoeffler (2004); Hegre and Sambanis (2006); Urdal (2011) contain strong evidence that poor countries with low GDP per capita and weak institutions are far more likely to experience internal armed conflict and civil war. Poor countries more frequently experience greater conflict events of instability, including internal war, than middle-income or wealthy countries. Poor countries, as can be observed from the literature, are mostly characterized by weak governance, non-inclusive political systems, high levels of corruption, and limited capacity to provide their citizens with basic social services protection of lives and properties, as well as confront the many developmental challenges that they face. This often results in a lack of legitimacy which is regarded as central to state-building. Conflicts also distort development and are a major stimulant of poverty and proliferation of arms. Statistics have shown that although poverty rate is on the decline in much of the world, countries affected by violence are unfortunately not part of this improvement. The 2011 World Bank report states that "for every three years a country is affected by major violence (i.e. deaths incurred in war or high rates of homicide), poverty reduction lags behind by 2.7 per cent, and on average, a country that experienced major violence from 1981 to 2005 had poverty rates 21 per cent higher than a country that saw no violence".

Secondly, the change from autocratic to democratic rule has potential for violent conflicts. The various demonstrations in North Africa go to prove the fact that a gross absence of democratic principles has the capacity to trigger gross instability and encourage the spread of arms. Cilliers and Schünemann (2013) assert that, generally, high-income countries are democratic and low-income countries autocratic. However, they argue further that there is some evidence that this relationship has weakened in the recent past, perhaps as a result of the global push for democratization and the associated extent to which electoral (non genuine) democracy may have outrun substantive (genuine) democracy.

Further, countries with a relatively vast youthful population that suffers from large-scale exclusion also tend to be more prone to violence. This becomes particularly acute if education levels, rates of urbanization and unemployment are comparatively high. It is established that there is a relationship between marginalized young $\mathrm{men} /$ women and crime. In cases where there are more youths in poor countries there are always propensity for 
increased tendency for arms proliferation, risk of conflict and high rates of homicide, especially if these youths do not benefit from the economic development, employment opportunities, education and training opportunities, participation in governance among other opportunities that exist within the society. Cilliers and Schünemann (2013) reported that the median age forecasted for sub-Saharan Africa in 2013 was less than 19 years of age and expected to reach 25 only by 2046. Comparing this age range with those for Western Europe, which stands at 43 years of age and almost 46 for Japan; more than double of the Sub Saharan Africa median age, it is not entirely wrong to assert along with these scholars, that nearly 49 per cent of the total population of sub-Saharan Africa falls within the age category of 15 to 29 , the grouping generally associated with a youth population. Hence, the proportion of youths in sub-Saharan Africa is also significantly higher than those of any other of the global subregions used by the UN for population projections. McLean Hilker and Fraser (2009) noted that countries with relatively high education levels, low employment levels and high rates of urbanization are more likely to experience internal violence than countries with the same income level but without these characteristics.

The World Bank Development Report 2011 stated that " 90 per cent of the civil wars in the last decade occurred in countries that had already had a civil war in the last 30 years". It can be argued that globally, there is more likelihood for wars or other violent forms of conflicts to repeat themselves in a particular country, thereby stunting development in the region. The Democratic Republic of Congo, the Central African Republic, Chad and a few other countries on the continent, appear to be plagued with similar tendencies.

Another factor that contains high propensity for the proliferation of arms and resultant conflict is the situation of a country in a neighborhood that is conflict-ridden; surrounded by four or more countries that are in conflict. The 2011 World Development Report asserts that, "a country making development advances, such as Tanzania, loses an estimated 0.7 per cent of GDP every year for each neighbour in conflict". On the other hand, neighbouring countries that have a higher risk of degenerating into conflict are a safer haven for rebel groups and insurgents and other armed groups (Hegre, Håvard et al., 2012). Buhaug and Gleditsch (2008), Gleditsch and Ward (2000), Salehyan and Gleditsch (2006), Gleditsch (2007) assert that proximity to other conflicts and/or countries with high rates of violent crime and illicit arms trafficking have negative effects as opposed to being in a neighbourhood that enjoys relative peace.

Finally, but by no means the least, poor governance, self-serving leadership and the impact of excessive dependence on commodity exports as well as its associated implications are a major source of contemporary conflict in Africa. The relationship between governance and the 'thickness' of domestic capacity, Cilliers and Schünemann (2013) argue are an important factor to be put into consideration. Such a relationship should bring about the ability to provide domestic security, the capacity to effectively administer the territorial area, provide public services to citizens, among others. When a country is able to provide a responsible governance mechanism that is sensitive to the developmental and welfare needs of the populace, conflict is kept several miles away.

\section{Which Way Forward?}

Conflict, arguably, would remain a constant phenomenon on the continent for the foreseeable future, since conflicts cannot be out-rightly prevented. However, the scale or magnitude of conflict situations that prevail in Africa, especially issues of terrorism, insurgency and illicit transnational trafficking and trades usually perpetrated by civilians, can be prevented from developing further than it already has. Measures for preventing the widespread nature of such conflicts must take sincere national, regional and international dimensions, if any significant results are to be achieved.

Civilians, no doubt, have increasingly become major actors in armed conflicts in Africa, and as regional and international organizations fight to protect civilian victims in armed conflicts, there should also be more specific policies to discourage and combat civilians inducing and engaging in violent armed conflict situations in Africa.

\section{Bibliographical References}

[1]. Alpers, P. and Wilson, M. (2012), Guns in Central Africa: Firearms, armed violence and gun law, Sydney School of Public Health, University of Sydney, GunPolicy.org, 17 December. Accessed 24 January 2014. http://www.gunpolicy.org/firearms/region/central-africa

[2]. Alpers, P. and Wilson, M. (2012), Guns in North Africa: Small arms policy, firearm injury and gun law, Sydney School of Public Health, University of Sydney, GunPolicy.org, 17 December. Accessed 24 January 2014.2 at: http://www.gunpolicy.org/firearms/region/north-africa

[3]. Annan, K. (2000), 'Freedom from Fear: Small Arms.' Report of the Secretary-General to the Millennium Assembly of the United Nations, United Nations General Assembly.

[4]. Ansari, H. A. (1984), 'Sectarian Conflict in Egypt and the Political Expediency of Religion',

[5]. The Middle East Journal, Vol. 38.

[6]. Batchelor, P. (2001), 'Small Arms, Big Business: Products and Producers.' Small Arms Survey 2001: Profiling the Problem, Oxford: Oxford University Press.

[7]. Batchelor, P. (2003), 'Workshops and Factories: Products and Producers.' Small Arms Survey 2003: Development Denied, Oxford: Oxford University Press. 
[8]. Becker, G. (1976); The Economic Approach to Human Behavior, Chicago and London: The

[9]. University of Chicago Press, pp. 3-14.

[10]. Bethany, L. and Gleditsch, N.P. (2005), Monitoring trends in global combat: a new dataset of battle deaths, European Journal of Population, 21(2-3) (2005).

[11]. Buhaug, H and Gleditsch, K. S. (2008), Contagion or confusion?, Why conflicts cluster in space, International Studies Quarterly 52(2) (2008).

[12]. Cilliers, J. and Schünemann, J. (2013), The Future of Intrastate Conflict in Africa: More Violence or Greater Peace? Institute for Security Studies (ISS)

[13]. Collier, P. and Hoeffler, A. (2004), Greed and grievance in civil war, Oxford Economic Papers, New Series 56(4) (2004).

[14]. Dunnigan, J. F. and Bay, A. (1996), A Quick and Dirty Guide to War. $3^{\text {rd }}$ edition, New York: William Morrow and Company

[15]. Elster, J. (1989); Social Norms and Economic Theory, Journal of Economic Perspectives,

[16]. American Economic Association, vol. 3(4), pages 99-117.

[17]. Evans, G. (2006), From Humanitarian Intervention to the Responsibility to Protect, Keynote Address by Gareth Evans, President of International Crisis Group and Co-Chair of the International Commission on Intervention and State Sovereignty 2001, to Symposium on Humanitarian Intervention, University of Wisconsin, Madison, 31 March 2006.

[18]. Fahrenthold, D. A. and Kunkle, F. (2009), 'Bullets are Speeding Faster Out of Gun Shops in U.S.' Washington Post.

[19]. Fearon, J. D. and Laitin, D. D. (2003), Ethnicity, insurgency, and civil war, American Political Science Review, 97(1) (2003).

[20]. Geneva Declaration 2008, 'Dimensions of Armed Violence.' Global Burden of Armed Violence, Geneva: Geneva Declaration on Armed Violence and Development Secretariat.

[21]. Geneva Declaration Secretariat, Global burden of armed violence 2011.

[22]. Gleditsch, K. S. and Ward, M. D. (2000), War and peace in space and time: the role of democratization, International Studies Quarterly 44(1) (2000).

[23]. Gleditsch, K. S. (2007), Transnational dimensions of civil war, Journal of Peace Research 44(3) (2007).

[24]. Green, D. P. and Shapiro, I. (1996); Pathologies of Rational Choice Theory: A Critique of Applications in Political Science, New Haven, CT: Yale University Press.

[25]. Green, S. L. (2002), Rational Choice Theory: An Overview, Baylor University.

[26]. Hashim, A. B. (1997), The Fallen State: Dissonance, Dictatorship and Death in Somalia. Lanham, MD: University Press of America.

[27]. Hegre, H and Sambanis, N. (2006), Sensitivity analysis of empirical results on civil war onset, Journal of Conflict Resolution, 50(4) (2006).

[28]. Hegre, H.; Karlsen, J.; Nygard, H. M.; Strand, H. and Urdal, H. (2012) Predicting Armed Conflict, 2010-2050. International Studies Quarterly, International Studies Association

[29]. Hilker, L. M. and Fraser, E. (2009), Youth exclusion, violence, conflict and fragile states, Report prepared for DFID's Equity and Rights Team (2009).

[30]. HIIK, Heidelberg Conflict Barometer, 2011.

[31]. Hogarth, R. M. and Reder, M. W. (1987); Rational Choice: The Contrast between Economics and Psychology, Chicago and London: The University of Chicago Press

[32]. IANSA 2006, 'A Thousand People Die Every Day.' Bringing the Global Gun Crisis Under Control, London: International Action Network on Small Arms.

[33]. Karp, A. (2007), 'Completing the Count: Civilian firearms' Small Arms Survey 2007: Guns and the City, Cambridge: Cambridge University Press

[34]. Lee, B.; Preston, F.; Kooroshy, J.; Bailey, R.; and Lahn, G. (2012), Resource futures, London: Chatham House, Royal Institute of International Affairs, 2012, 152.

[35]. Melander, E.; Oberg, M. And Hall, J. (2006), The 'New Wars' Debate Revisited: An Empirical

[36]. Evaluation of the Atrociousness of 'New Wars', Uppsala Peace Research Papers No. 9, Department of peace and Conflict Research, Uppsala University, Sweden.

[37]. Mortimer, R. A. (1996), 'Islamists, Soldiers and Democrats: The Second Algerian War', The

[38]. Middle East Journal, Vol. 50.

[39]. National Intelligence Council (NIC), Global trends 2030: alternative worlds, 2012. Available at www.dni.gov/ nic/globaltrends

[40]. Nyakanvzi, E. (1998), Genocide: Rwanda and Burundi. Rochester, VT: Schenkman Books

[41]. Ogu, M. I. (2013), Rational Choice Theory: Assumptions, Strengths, and Greatest Weaknesses in Application Outside the Western Milieu Context, Arabian Journal of Business and Management Review (Nigerian Chapter) Vol. 1, No. 3, 2013

[42]. Osaghae, E. E. (1994), Persistent Conflict in Africa: Management Failure or Endemic Catastrophe?, South African Journal of International Affairs. Vol. 2, Issue 1.

[43]. Radnitzky, G. and Bernholz, P. (eds.) (1987); Economic Imperialism: The Economic Approach Applied Outside the Field of Economics, New York: Paragon House Publishers.

[44]. Renner, M. (2008), 'Vehicle Production Rises, But Few Cars Are 'Green'.' Vital Signs Online: Transportation and Communication, Washington DC: Worldwatch Institute.

[45]. Salehyan, I. and Gleditsch, K. S. (2006), Refugees and the spread of civil war, International Organization, 60(2) (2006).

[46]. Schraeder, P. J. (2004), African Politics and Society: A Mosaic in Transformation (2 ${ }^{\text {nd }}$ Edition). USA: Wadsworth CENCAGE Learning

[47]. Shaw, M. and Reitano, T. (2013), The evolution of organized crime in Africa: towards a new response, Institute for Security Studies, Paper 244 (April 2013). All available at www.issafrica.org

[48]. SpyGhana report, Tuesday, October 15, 2013

[49]. Straus, S. (2012), Wars do end! Changing patterns of political violence in sub-Saharan Africa, African Affairs, Volume 111 , Issue 443.

[50]. Swedborg, R. (1990); Economics and Sociology, Princeton: Princeton University Press.

[51]. Tell Magazine of August 26, 2013

[52]. Urdal, H. (2011), Demography and armed conflict: assessing the role of population growth and youth bulges, Centre for Research on Peace and Development, Working paper No. 2, 2011, 1

[53]. World Bank, World development report 2011, 60.

[54]. 147 Oxfam Briefing Paper May 2011, Protection of Civilians in 2010: Facts, figures, and the UN Security Council's response

[55]. http://www.smallarmssurvey.org/weapons-and-markets/definitions.html accessed January 26, 2014. 